Pobrane z czasopisma Annales H - Oeconomia http://oeconomia.annales.umcs.pl Data: 26/04/2023 17:23:49

DOI:10.17951/h.2017.51.3.147

\begin{tabular}{lcl}
\hline \multicolumn{1}{c}{ A N N A L E S } \\
UNIVERSITATIS MARIAE CURIE-SKŁODOWSKA \\
LUBLIN - POLONIA \\
VOL. LI, 3 & SECTIO H \\
\hline
\end{tabular}

Maria Curie-Skłodowska University in Lublin, Faculty of Economics

ŁUKASZ WIECHETEK

lukasz.wiechetek@umcs.pl

\title{
Introduction of Geographic Information Systems into Business Education. The Case of Polish Students of Logistics
}

Wprowadzenie systemów informacji geograficznej do edukacji biznesowej na przykładzie polskich studentów logistyki

Keywords: GIS; geographic information system; curriculum; GIS perception; student's perspective; GIS framework

Slowa kluczowe: GIS; system informacji przestrzennej; program przedmiotu; postrzeganie GIS; perspektywa studenta; sylabus

JEL code: L86; M20; D83

\section{Introduction}

\section{Geographic information system}

A geographic information system (GIS) is a computer system for capturing, storing and visualizing data related to positions on Earth's surface [National Geographic Society p. 1]. It can be considered as a special type of decision support system [Fuller and Bradbard 2009, p. 163]. GIS technology can be used for visualization of different phenomena and discover how they relate to each other. GIS is a system for collecting, processing and sharing data containing spatial information. One of the main elements of GIS is a database containing spatial and descriptive data. The 
main functions of GIS are data capturing (manual data entry, import from external sources, maps digitalization), data management (validation, searching, filtering, access control), data processing (conversion, transformation, aggregation, spatial analysis, statistical analysis) and data sharing (reports generating, maps creation, data export, Internet publishing).

GIS can be used in many areas of human activities [Miller et al. 2014, p. 31; King and Arnette 2011, p. 326; Fuller and Bradbard 2009, p. 167; Estaville 2007, p. 443; Miller et al. 2006, p. 75]:

- archaeology (location of excavations),

- architecture (spatial planning, especially the urban and regional),

- geology (presentation of the structure and processes occurring inside the Earth),

- meteorology (forecasts visualization),

- seismology (presentation of areas with high risk of earthquake),

- environmental protection (pollution and pollutants analysis, environmental monitoring),

- forestry and agriculture (mapping of agricultural land and forests),

- statistics (visualization of social, economic and demographic phenomena),

- trade (market analysis, planning of business hubs localization),

- aviation (grid connections analysis, location of airports),

- marketing (market analysis, advertising campaigns planning),

- education (presentation of the level of education, location of educational centers),

- emergency services (quick location, identification of vulnerable zones),

- transportation (routes optimization transport systems design),

- tourism (tourist routes design and visualization, maps of tourist attractions),

- insurance (analysis of events and their spatial variability),

- army (operations planning and monitoring, command, logistics),

- public administration (land and real estate management),

- infrastructure management (pipelines inventory, infrastructure design),

- buildings administration (inventory, building plans).

Nowadays we can observe fast growth of college courses and programs dealing with spatial information [Wikle and Fagin 2014, p. 574]. GIS technology can be used in a number of areas and ways, that is why many IT companies and non-profit organizations create different kinds of GIS tools. The main classes of GIS software are: desktop GIS (on-premise software for map creation, management and analyzing spatial data), DBMS (systems for spatial data management), GIS servers (on-line software for map creation, management and analyzing the spatial data), web GIS (mainly for publishing spatial data and quick analysis) and mobile GIS (tools for mobile devices) [Gisplay, p. 1]. The most popular GIS tools include ArcGIS, QGIS, MapInfo, AutoCAD, Google Maps/Earth, Global Mapper [Software. informer p. 1]. 


\subsection{GIS in business higher education}

One of the most important sources of information for curriculum development in geospatial domain is the Geographic Information Science and Technology Body of Knowledge (GIS\&TBoK) [Wallentin et al. 2015, p. 439]. It was developed because of rapid growth of the GIS market, increasing size of geospatial workforce, lack of adequate supply for geospatial professionals and inadequate preparation of GIS professionals [DiBiase et al. 2006, pp. 9-10]. GIS\&TBoK was developed by GIS community and contains the required knowledge and skills from the area of geographic information systems and technology. It can be used by educators, curriculum developers, certification organizations as a reference book. Although it is a great source of information about analytical methods, cartography and visualization, design aspects, data modeling and manipulation, geospatial data and geocomputation [DiBiase et al. 2006, pp. v-vi], its content should be updated because of new market needs like handling of highly abundant spatial data, developing programming competences and skills in applications usage, or fast development of web-based solutions [Wallentin et al. 2015, p. 439]. In the last three decades, we can observe great development and investments in GIS education: software purchases, developing new curricula and path of certifications [Fagin and Wikle 2011, p. 1]. Therefore, new research are performed in order to improve GIS courses' quality, effectiveness and adjustment to market needs.

Decision-making process for location of new business including: locations selecting, gathering spatial data about locations, data analysis and final recommendation was the main step of the project proposed by Fuller and Bradbard [2009, p. 163]. The project was developed to stress the entrepreneurial application of GIS. The authors concluded that cities should support GIS web sites and merge digital maps with the data about local markets. These sites could be used by companies and entrepreneurs to support decision making processes.

There is also a great need for right preparation and professional development of GIS educators [Fagin and Wikle 2011, p. 1]. Holstein [2015, p. 38] prepared an online survey and examined 115 academic libraries. She collected information about offered services, education and trainings for GIS departments staff members. Holstein recommends developing a geographic information service center in the library that will offer a comprehensive service. Some kind of geospatial center with computer hardware, new GIS tools and technologies, large geospatial data sets and well trained staff that can assist students [Holstein 2015, p. 48].

GIS classes are incorporated into business schools curricula. In late 2006 and early 2007, in order to know if US institutions of higher education incorporate GIS courses into their curricula, Estaville explored programmes of 140 public and private institutions and found out that only five business colleges offer GIS courses [Estaville 2007, p. 443]. Wikle and Fagin [2014, p. 574] explored 312 GIS course syllabi used at US colleges and universities. They found that hands-on activities were mainly 
used as evaluation methods. The syllabi content and GIS software used were rather similar. Most courses contained topics like: vector analytic operations, data models, and data creation/acquisition/editing.

Miller et al. [2014, p. 31] proposed the way of enhancing learning in marketing with the use of web-based business GIS. They present RacerGISOnline system that integrates GIS tools into several marketing courses. The tool can be used by the marketing faculty in any institution without extra costs. During the implementation of the system, they faced two main obstacles: a technical one, concerning the effectiveness of modules, and the second obstacle which related to little knowledge and skills in the area of GIS among marketing faculty staff. The constraints and barriers of integrating GIS solutions into business classes were presented by Miller, Mangold and Holmes. They indicated high initial costs (expensive software and high performance hardware); cost and availability of well-trained faculty staff and time needed for training and curricula preparation [Miller et al. 2006, p. 75].

Also King and Arnette [2011, p. 325] described the possibility of integrating geographic information system into business school curriculum. They compared and discussed spatial modeling in comparison with standard data modeling, taught in business schools. They showed how to use relational databases like MySQL and PostgreSQL for spatial data storing and analyses. They also proposed techniques for evolutionary integration of location intelligence into business curriculum without the need to learn new complex GIS tools.

\section{GIS course framework}

\subsection{Organization of the classes}

The E-logistics and GIS classes were carried out among first-year Master's students of logistics. Full-time students had 15 hours of lectures and 15 hours of laboratories. Part-time students had 9 hours of lectures and 9 hours of laboratories. The classes were carried out in a computer lab where students had access to computers equipped with Windows operating system, and could install any necessary GIS software (with the consent of the teacher). The general schedule of lab classes is presented in Figure 1.

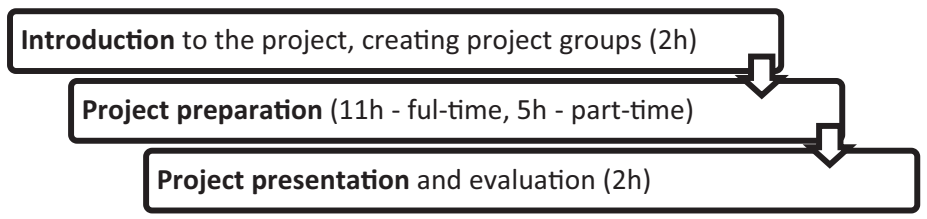

Figure 1. The general schedule of GIS lab classes 
Projects were carried out in groups of 3 or 4 students. At the first meeting the teacher introduced the GIS fundamentals and the main aims of the project. The students were asked to divide themselves into groups, however, they were informed that they should work together and monitor each other because during the last meeting one randomly selected member of the group will present the project on behalf of the entire team.

Auxiliary materials: project framework, links to GIS portals, characteristics of GIS standards and information about the most popular GIS tools were available on e-learning platform based on Moodle called "Virtual Campus".

During the project preparation stage, students created project documentation in text editor, organized data for visualization (mainly in Microsoft Excel), developed short project presentation in Microsoft PowerPoint. Project groups used own selected and installed tool for visualization GIS or e-logistics projects.

The last meeting was to present the project outcomes. The randomly selected member of the group presented the developed project. During the presentation, students showed a short, one-page project description, presented a PowerPoint slideshow (characteristic of used applications) and, finally, demonstrated the main steps of final project preparation using a chosen GIS tool and final visualization. After the presentation, the teacher and the members of the other project groups evaluated the presentations using simple assessment questionnaire developed in the Moodle platform.

\subsection{The main steps of the project development}

During the classes each group carried out the project in the area of e-logistics or GIS. Students performing the project should have achieved three milestones: information cart, live demonstration and tool presentation (Figure 2).

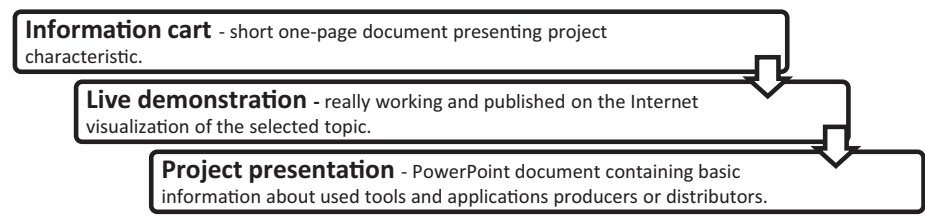

Figure 2. The project milestones

Source: Author's own work.

At the beginning of the course, each group prepared a short document presenting the team members, title of the project, project description, used data sources and a list of potential applications for visualization (Figure 3).

After preparing the project information card, each group tried to gather necessary data and visualize it using a selected GIS system. Students could choose their own project subject and their own IT tool for visualization. During the laboratories teacher presented how to visualize data with Google Maps, QGIS and Power View 


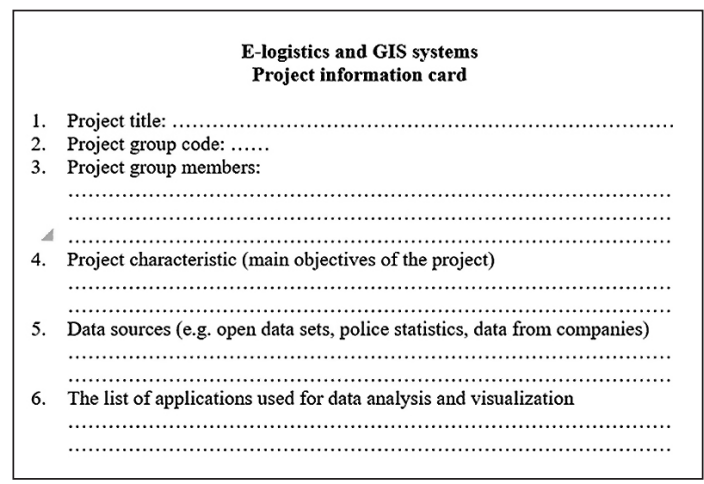

Figure 3. The project information card

Source: Author's own work.

- an add-in for Microsoft Excel. However, each project group could choose, install and learn its own tool. Finally, when the group prepared live demonstration, the last step was to develop a PowerPoint presentation containing the main information about a used tool and the created project. The main requirements for the presentation are shown in Table 1.

Table 1. The presentation requirements

\begin{tabular}{|c|l|}
\hline No. & \multicolumn{1}{|c|}{ Requirement } \\
\hline 1. & The presentation should contain from 10 to 15 slides in PowerPoint \\
\hline 2. & The maximum duration of presentation is 10 minutes \\
\hline & $\begin{array}{l}\text { Each slide should contain the following information: } \\
\text { - General characteristics of the system } \\
\text { - General characteristics of the system producer } \\
\text { - The list of modules included in the system } \\
\text { - The main areas of system application } \\
\text { - The basic functions of the system } \\
\text { - The cost of system implementing and using } \\
\text { - Hardware and software requirements } \\
\text { - Sample use case of the system } \\
\text { - Project description } \\
\text { - Information about the source of data used in project } \\
\text { - Finally made visualization (screenshot) } \\
\text { - The list of sources used to develop the presentation }\end{array}$ \\
\hline
\end{tabular}

Source: Author's own work.

The projects were presented during the last meeting. The presenting person was drawn by the teacher using a macro definition written in VBA for Excel. Each selected student had about 20 minutes for presenting all three outcomes: information card, slideshow and live demonstration. After the presentation, the teacher and other groups assessed each project and presentation style using a short questionnaire prepared in the Moodle platform. 


\subsection{Final projects}

Students could prepare final projects in the area of e-logistics or GIS. During the final demonstration, a chosen representative of project group presented the project information card, slideshow about a used tool and live demonstration of the developed project. Live demonstration contained some information about a used tool (application interface, basic functionality), showed the main stages of created project (data acquisition, data transformation, visualization) and final visualization. Requirements for live demonstration are shown in Table 2.

Table 2. The demonstration requirements

\begin{tabular}{|c|l|}
\hline No. & \multicolumn{1}{|c|}{ Demonstration requirement } \\
\hline 1. & The demonstration should last up to 10 minutes \\
\hline 2. & The show can be carried out using one's own computer or a computer available in the lab \\
\hline & $\begin{array}{l}\text { Elements of the tool demonstration: } \\
\text { - general structure of the system (interface, navigation, configuration, help system) } \\
\text { - data entering (manual data entry, import from a file, searching for information in the system) } \\
\text { - the possibility of using add-ins } \\
\text { - installation of additional packages (plug-in) } \\
\text { - ability to use programming interface (API) } \\
\text { - the possibility of system cooperation with external tools (import, export standards) }\end{array}$ \\
\hline 4. & $\begin{array}{l}\text { Demonstration of the main steps of project creation: } \\
\text { - entering sample geospatial information } \\
\text { - generating sample visualization (report, map) } \\
\text { - providing maps or report online } \\
\text { demonstration of interactive capabilities of visualization }\end{array}$ \\
\hline
\end{tabular}

Source: Author's own work.

Sample visualizations (maps) presented by students were shown in Table 3 .

Students developed a lot of different projects in the area of education, transportation, trade, security and culture. They used different GIS tools (online and on-premise). The most popular were QGIS, ArcGIS, SASPlanet and Google Maps.

Table 3. Sample GIS visualizations

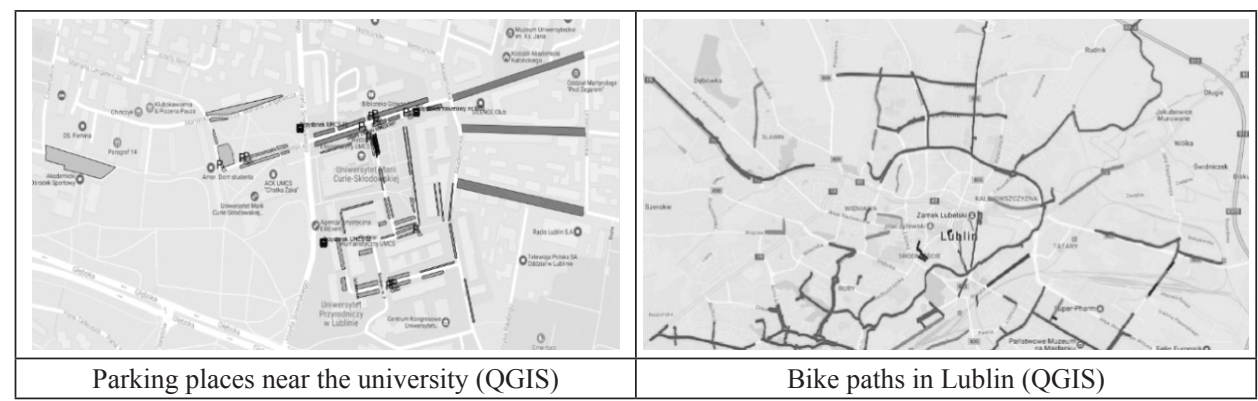


Pobrane z czasopisma Annales H - Oeconomia http://oeconomia.annales.umcs.pl

Data: 26/04/2023 17:23:49

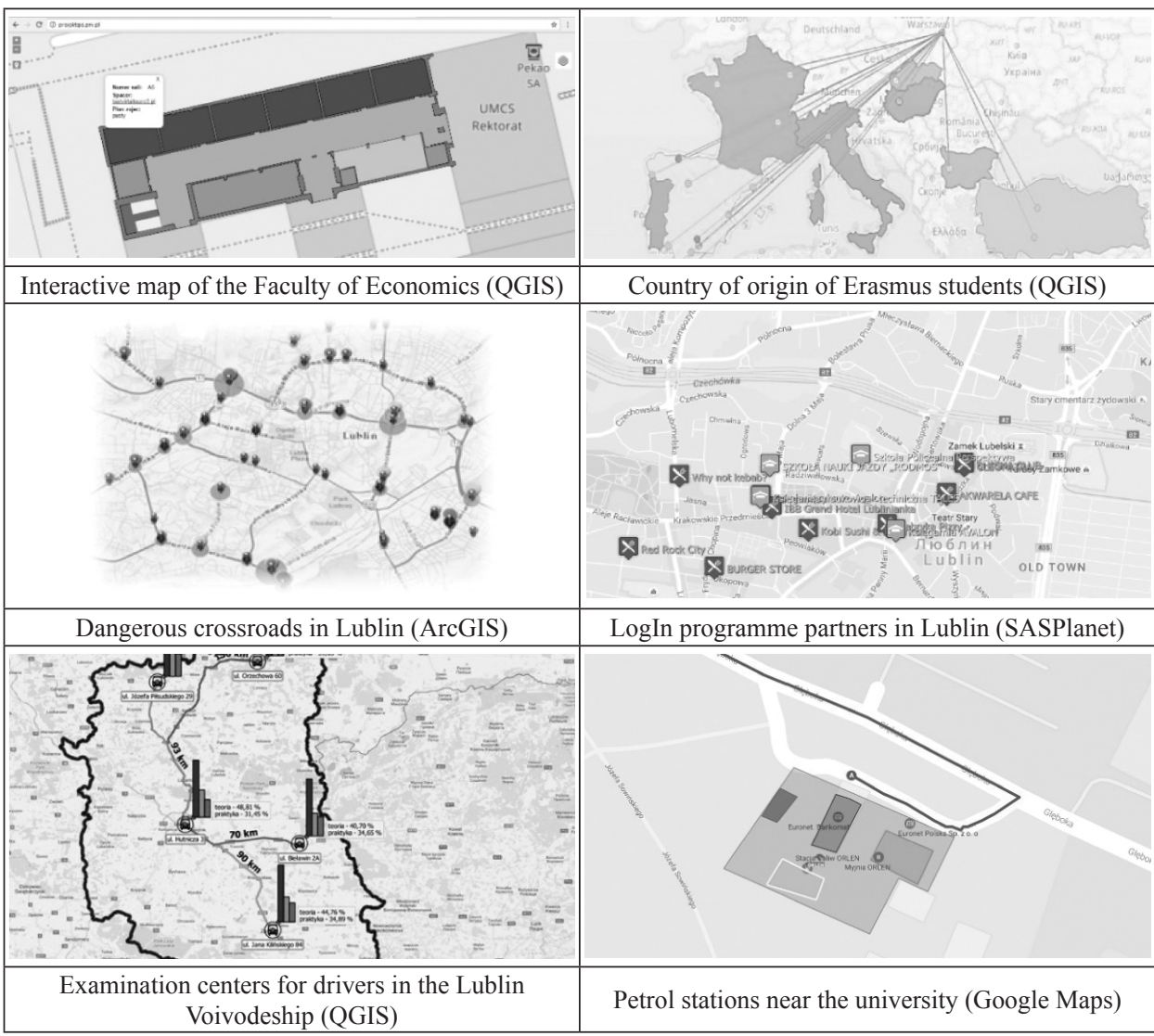

Source: Faculty of Economics students' work.

\section{Students' opinions about GIS and the programme}

In order to know the students' opinions about geographical information systems and their comments on GIS way of teaching, the author prepared the online questionnaire that was completed by the students after the last meeting.

\subsection{Research questions}

The author examined the students of logistics Master's programme in order to get the answers to the following research questions:

- Did the students know the term "geographical information system" before attending the GIS classes?

- What are the main sources of knowledge about GIS?

- How do the students understand the "GIS" term? 
- Would the students like to use the opportunities offered by the GIS in future work?

- How did the students get knowledge about GIS?

- How do the students learn to use GIS software?

\subsection{Research procedure}

The author divided the research procedure into the following stages: research questions, literature analysis, project framework preparation, observation of the course participants, survey preparation, data gathering, statistical analysis, final conclusions and plans for the future. The research procedure was presented in Figure 4.

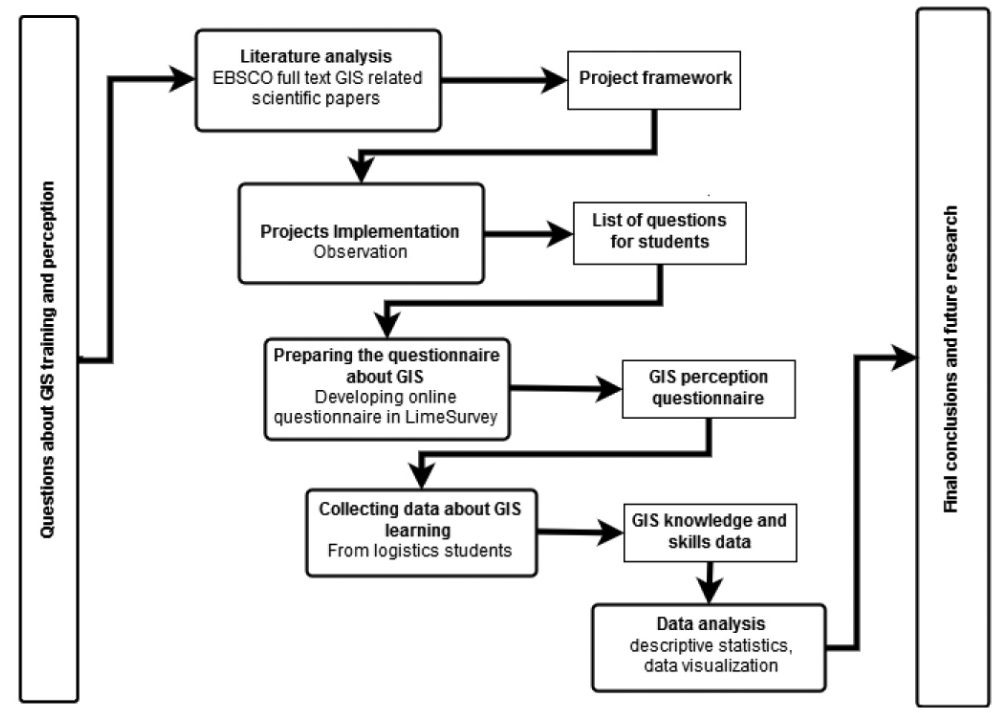

Figure 4. The research procedure

Source: Author's own work.

\subsection{Data analysis}

\section{The characteristics of the respondents}

In order to get the answers to the research questions, the author prepared the survey for logistics students, attendants of the E-logistics and GIS course. All the 116 participants ( 86 full-time and 30 part-time) were asked to fill in the anonymous survey. 96 respondents ( 70 full-time students and 26 part-time students) completed the survey. The characteristic of the surveyed students was presented in Table 4. 
Pobrane z czasopisma Annales H - Oeconomia http://oeconomia.annales.umcs.pl

Data: 26/04/2023 17:23:49

Table 4. The characteristic of the surveyed students

\begin{tabular}{|l|l|c|c|}
\hline \multicolumn{2}{|c|}{ Characteristic } & Number & $(\%)$ \\
\hline \multirow{5}{*}{ Gender } & woman & 46 & $48 \%$ \\
\cline { 2 - 4 } & man & 50 & $52 \%$ \\
\hline \multirow{5}{*}{ Age } & 20 & 3 & $3 \%$ \\
\cline { 2 - 4 } & 21 & 6 & $6 \%$ \\
\cline { 2 - 4 } & 22 & 38 & $40 \%$ \\
\cline { 2 - 4 } & 23 & 27 & $28 \%$ \\
\cline { 2 - 4 } & 24 & 13 & $14 \%$ \\
\cline { 2 - 4 } & 25 & 6 & $6 \%$ \\
\cline { 2 - 4 } & $>25$ & 26 & $3 \%$ \\
\hline \multirow{5}{*}{ Status } & part-time & 70 & $73 \%$ \\
\cline { 2 - 4 } & full-time & 44 & $46 \%$ \\
\hline \multirow{5}{*}{ Interest in IT technology } & employed & 52 & $54 \%$ \\
\cline { 2 - 4 } & not employed & 12 & $0 \%$ \\
\cline { 2 - 4 } & definitely no & 21 & $22 \%$ \\
\cline { 2 - 4 } & rather no & 48 & $50 \%$ \\
\cline { 2 - 4 } & no opinion & 15 & $16 \%$ \\
\cline { 2 - 4 } & rather yes & & \\
\cline { 2 - 4 } & definitely yes & $27 \%$ \\
\hline
\end{tabular}

Source: Author's own work.

$52 \%$ of the respondents were men. The age of the respondents was from 20 to 28 years. The majority of students were 22 years old. Most of the respondents were full-time students (73\%) almost half of the surveyed students were employed (46\%). The respondents expressed interest in IT technology, $66 \%$ of them were rather interested $(50 \%)$ or definitely interested $(16 \%)$ in IT.

\section{Students' knowledge about GIS}

The respondents stated that before attending the E-logistics and GIS classes they had very little or no knowledge about geographic information systems (Figure 5).

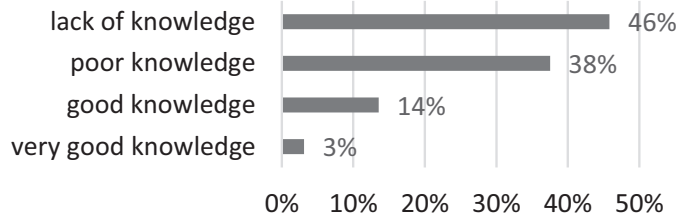

Figure 5. Knowledge of GIS

Source: Author's own work

Respondents indicated a complete lack of $(46 \%)$ or poor knowledge $(38 \%)$ of the GIS term before attending the course. Only 17 respondents answered that their knowledge about GIS at the beginning of the classes was good (14\%) or very good (3\%). 


\section{The source of knowledge about GIS}

In the survey, students were asked about sources of knowledge about GIS. In this question they could choose more than one answer from the list of the following categories: conversations with friends, this survey, Internet sources, journals and business reports, public media (radio, TV), social media and university courses. Most respondents indicated university courses (96\%) and Internet sources (49\%). The least popular sources of information were journals, business reports (13\%) and social media (6\%). $4 \%$ of the respondents stated that they learned about GIS from this research (Figure 6).

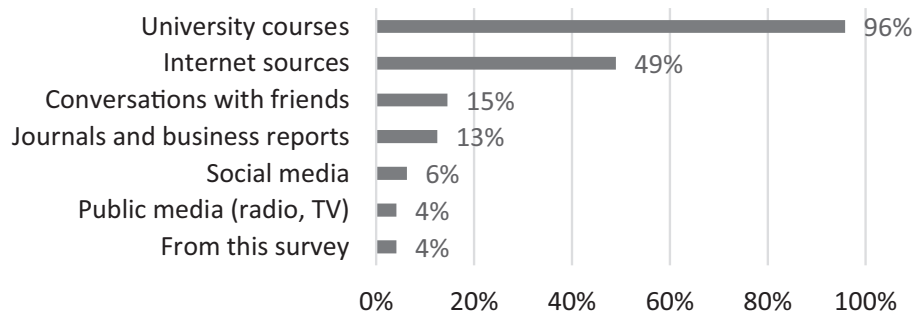

Figure 6. Source of knowledge about GIS.

Source: Author's own work.

The respondents indicated that the most common ways of acquiring knowledge in the area of GIS were watching video tutorials (66\%), instructions from the teacher $(64 \%)$ work in groups $(58 \%)$, information presented in online forums $(46 \%)$ and materials published by software vendor (42\%) (Figure 7).

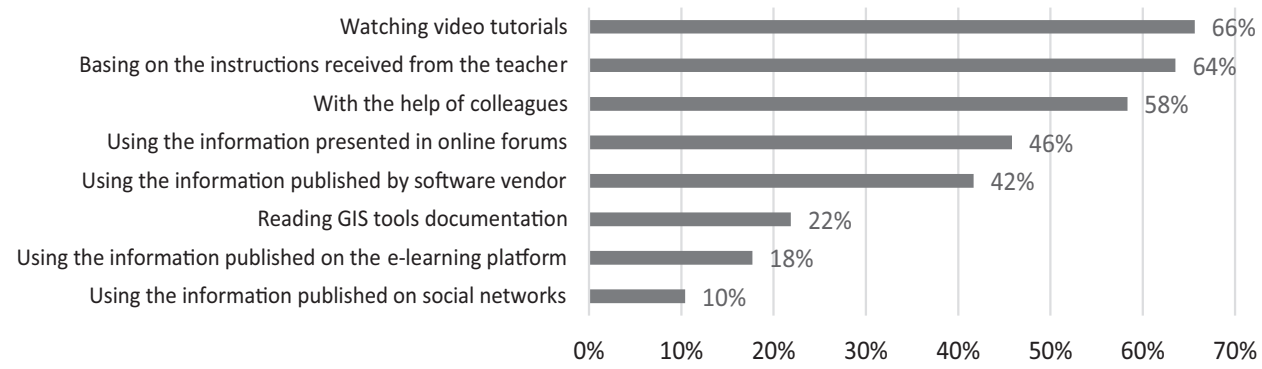

Figure 7. Ways of acquiring knowledge in the area of GIS

Source: Author's own work.

The least popular ways of learning were reading GIS tools documentation (22\%), using university e-learning platforms $(18 \%)$ and reading information published on social networks $(10 \%)$. A small group of respondents also indicated self-learning, university lectures and the undergraduate classes. 


\section{Willingness to use geographic information system}

Asked students of logistics can be seen as supporters of GIS solutions. Almost $70 \%$ indicated that they would like to use the GIS applications in present or future work. Slightly less than $15 \%$ stated that they are not willing to use GIS in their work (Figure 8).

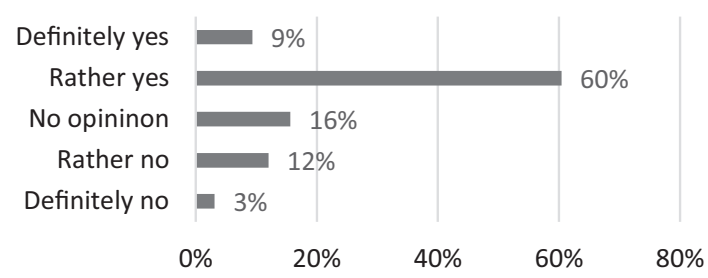

Figure 8. Willingness to use geographic information system in future work

Source: Author's own work.

\section{Research limitations and future research}

The revised literature suggests that geographic information systems have a lot of areas of usage and are increasingly used to support business processes. Therefore, there is a need of preparing GIS courses for business students and monitor the effectiveness of the training process. The performed research was limited only to the students of logistics at the Faculty of Economics (MCSU) that may limit the generalizability of the findings. Therefore, future research would be conducted to compare the presented findings with the opinions of students of different fields and a wider group of potential GIS users, people of various interests, skills and age. The author wants to collect and analyze more detailed information about GIS perception and GIS learning process, mainly related to: open data sources for GIS projects development, best GIS applications for educational purposes, the main barriers faced by students in the GIS educational process and what kind of knowledge and skills acquired during the GIS courses will be most useful in future work.

\section{Conclusions}

The GIS projects were developed from October 2016 to January 2017. The quantitative research was conducted on a sample of 96 respondents, Master's students of logistics in January 2017. The study involved young people between 20 and 28 years old, mainly full-time students (73\%). $48 \%$ of asked people were male.

The performed analysis and author's observation (during the classes) shows that young people were keen on GIS solutions, about $70 \%$ would like to use geographic information systems in their future work. 
The completed observations and data analysis indicate that:

- At the beginning of the project, the students had a lot of concerns related mainly with data collecting procedure and lack of knowledge and skills in using GIS software.

- Quantitative research showed that at the beginning of Master's programme, students had no or little knowledge about geographic information systems ( $84 \%$ of the respondents).

- There were three main sources of knowledge about GIS: university courses (96\%), Internet sources (49\%) and conversations with friends (15\%).

- Students acquired knowledge about GIS and about using geographic information systems mainly by watching video tutorials $(66 \%)$, listening to instructions/watching demonstrations prepared by the teacher (64\%) and working in groups with colleagues (58\%).

- The surveyed students can be seen as supporters of GIS technologies. Above $70 \%$ of respondents would like to use GIS solutions in future work.

- The project development stage shoved that the examined students like and know how to work in small groups. They supported each other, they also exchanged knowledge and skills between the project groups.

\section{Bibliography}

DiBiase, D., Demers, M., Johnson, A., Kemp, K., Taylor Luck, A., Plewe, B. Wentz, E. (eds.), Geographic Information Science and Technology Body of Knowledge, Association of American Geographers, Washington 2006.

Estaville, L.E., GIS and Colleges of Business: A Curricular Exploration, "Journal of Real Estate Literature" 2007, vol. 15 , no. 3 , pp. $441-448$.

Fagin, T., Wikle, T., The Instructor Element of GIS Instruction at US Colleges and Universities, "Transactions in GIS" 2011, vol. 15, no. 1 pp. 1-15.

Fuller, B. Bradbard, D., An Entrepreneurial Application of a Geographic Information System, "Decision Sciences Journal of Innovative Education” 2009, vol. 7, no. 1, pp. 163-170.

Holstein, A.L., Geographic Information and Technologies in Academic Libraries: An ARL Survey of Services and Support, "Information Technology \& Libraries" 2015, vol. 34, no. 1, pp. 38-51.

King, M., Arnette, A., Integrating Geographic Information Systems in Business School Curriculum: An Initial Example, "Decision Sciences Journal of Innovative Education" 2011, vol. 9, no. 3, pp. 325-347.

Miller, F., Mangold, W., Holmes, T., Integrating Geographic Information Systems (GIS) Applications into Business Courses Using Online Business Geographics Modules, "Journal of Education for Business" 2006, vol. 82, no. 2, pp. 74-79.

Miller, F., Mangold, W., Roach, J., Brockway, G., Johnston, T., Linnhoff, S., McNeely, S., Smith K., Holmes, T., RacerGISOnline: Enhancing Learning in Marketing Classes with Web-based Business GIS, "Marketing Education Review" 2014, vol. 24, no. 1, pp. 31-36.

National Geographic Society, http://www.nationalgeographic.org/encyclopedia/geographic-information-system-gis/ [access: 31.01.2017].

Geoinformation Portal gisplay.pl, Oprogramowanie GIS, http://www.gisplay.pl/gis/oprogramowanie-gis. html [access: 31.01 .2017$]$. 
Software.informer, Most popular GIS software, http://gis.software.informer.com/software/ [access: 31.01.2017].

Wallentin, G., Hofer, B., Traun, C., Assessment of Workforce Demands to Shape GIS\&T Education, "Transactions in GIS" 2015, vol. 19, no. 3, pp. 439-454.

Wikle, T., Fagin, T. GIS Course Planning: A Comparison of Syllabi at US College and Universities, "Transactions in GIS" 2014, vol. 18, no. 4, pp. 574-585.

\section{Introduction of Geographic Information Systems into Business Education. The Case of Polish Students of Logistics}

This article aims to extend current research in the area of teaching geographic information systems (GIS) in business faculties. GIS has a lot of areas of usage (logistics, trade, marketing, infrastructure management, public administration, archaeology, geology, meteorology forestry, agriculture environmental monitoring, aviation, statistics, education), however, it is not a popular subject especially in business school programs. Young people quickly learn and use new applications and technologies. Therefore, the author presents the GIS classes framework and the opinions of students about their knowledge and perception of GIS. The article contains the theoretical background of GIS and presents the main areas of geographic information systems usage. The main part of the paper is a framework of E-logistics and GIS programme prepared for the students of logistics at Maria Curie-Skłodowska University in Poland. The author also analyzes students' opinions about GIS and presents main conclusions derived from quantitative research conducted in a form of online questionnaire performed in January 2017 among a group of 96 students of logistics. At the end of the article, there can be found the proposal for future research. The author examined only the students of logistics at the Faculty of Economics, thus, a small group of young people. Some future research should be performed in order to compare the obtained results with GIS-related programmes from different universities in Poland and abroad.

\section{Wprowadzenie systemów informacji geograficznej do edukacji biznesowej na przykładzie polskich studentów logistyki}

Opracowanie zawiera wprowadzenie do tematyki GIS oraz przedstawia główne obszary wykorzystania systemów informacji geograficznej. Główną część pracy stanowi charakterystyka programu przedmiotu pn. E-logistyka i GIS przygotowanego dla studentów logistyki Uniwersytetu Marii Curie-Skłodowskiej w Lublinie. Autor analizuje także opinie studentów na temat GIS i przedstawia główne wnioski wynikające z badań ilościowych w formie kwestionariusza internetowego przeprowadzonego w styczniu 2017 r. wśród 96 studentów logistyki. Na końcu artykułu znajduje się propozycja dotycząca kontynuacji niniejszych badań. Autor zbadał opinie studentów logistyki na Wydziale Ekonomicznym UMCS, a więc niewielką grupę młodych ludzi. Przyszłe badania powinny być rozszerzone o inne grupy respondentów w celu porównania uzyskanych wyników z opiniami studentów z różnych kierunków studiów i uniwersytetów w Polsce i za granicą. 